\title{
A meta methodology of quality of academic failure studies in medical journals
}

\author{
Azadeh Fadavi Roodsari ${ }^{1}$, Keyvan Salehi ${ }^{2}$, Ebrahim Khodaii ${ }^{3}$, Ali Mogadamzadeh ${ }^{4}$, Mohammad \\ Javadipour $^{5}$ \\ 1. PhD Student of Educational Measurement and Evaluation, Department of Curriculum Development \& Instruction \\ Methods, Faculty of Psychology and Education, University of Tehran, Tehran, Iran. ORCID ID: 0000-0003-3245-7577 \\ 2. Assistant Professor, Department of Curriculum Development \& Instruction Methods, Faculty of Psychology and \\ Education, University of Tehran, Tehran, Iran., (Corresponding Author), Tel: +98 (21) 61117472, Email: \\ keyvansalehi@ut.ac.ir, ORCID ID: 0000-0001-8673-4248 \\ 3. Associate Professor, Department of Curriculum Development \& Instruction Methods, Faculty of Psychology and \\ Education, Head of Iran's Evaluation and Training Organization, University of Tehran, Tehran, Iran. ORCID ID: 0000-0002- \\ 5634-5003 \\ 4. Assistant Professor, Department of Curriculum Development \& Instruction Methods, Faculty of Psychology and \\ Education, University of Tehran, Tehran, Iran. ORCID ID: 0000-0002-3960-5037 \\ 5. Associate Professor, Department of Curriculum Development \& Instruction Methods, Faculty of Psychology and \\ Education, University of Tehran, Iran. ORCID ID: 0000-0002-2605-5312
}

ABSTRACT

Background and Aim: A review of the quality of the studies for the purpose of improvement of the future studies is one of the most important ways to achieve sustainable development and expand the knowledge in medical sciences. Considering the importance of medical students' education and their academic failure, the present study aimed at criticizing and representing the existing probelms in the elements of the methods of the articles in the field of academic failure published in medical journals.

Materials and Methods: The present study was a meta-method study and included all the the studies published in the Magiran, SID and Noormags databases. On the basis of our inclusion criteria we selected articles dealing with factors associated with academic failure in medical students published between 2000 and 2016 in valid internal journals. The exclusion criteria included different dates of publication, articles unrelated to academic failure and the studies on non-medical students. We found 346 articles. After exclusion of irrelevant studies, 22 articles were selected.

In order to analyze the findings, a first-order check list including elements of research method and approach, study population, study sample, sampling method, determination of sample size, hypothesis, assessment tools, reliability and validity was made.

Results: This study showed that the reviewed studies had problems in relation to sampling, data collection and research methods. And underestimation of these problems can raise challenges to the future studies.

Conclusion: It seems that, extreme attention to the content and lack of attention to the delicacies in the methodology section can lead to a decline in the quality of the researches. Using the results of these studies can be accompanied by fundamental problems and cannot always be cited.

Keywords: Meta-study, Meta-methodology, Research method, Academic failure

Received: June 19, 2019

Accepte: Oct 26, 2019

How to cite the article: Azadeh Fadavi Roodsari, Keyvan Salehi, Ebrahim Khodaii, Ali Mogadamzadeh, Mohammad Javadipour. A Meta Methodology of Quality of Academic Failure Studies in Medical Journals.SJKU 2020;25(4):103-114.

Copyright (C) 2018 the Author (s). Published by Kurdistan University of Medical Sciences. This is an open access article distributed under the terms of the Creative Commons Attribution-Non Commercial License 4.0 (CCBYNC), where it is permissible to download, share, remix, transform, and buildup the work provided it is properly cited. The work cannot be used commercially without permission from the journal 


\section{فراروش بررسى كيفيت مطالعات افت تحصيلى در مجلات علوم يز شيكى}

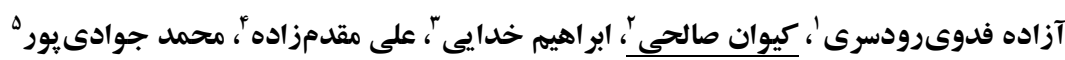

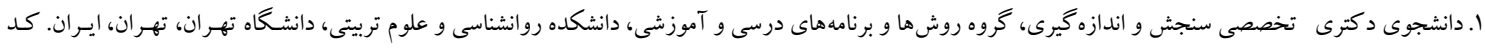

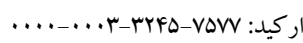

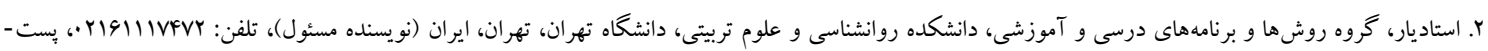

الكترونيك: keyvansalehi@ut.ac.ir، كد اركيد:

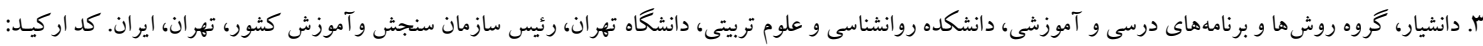

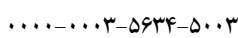

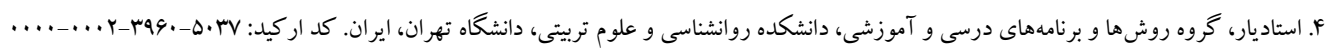

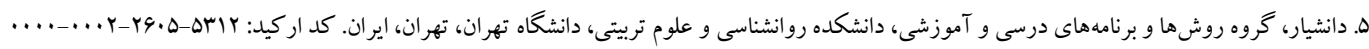

جـكيله

زمينه و هدف: نقد كيفيت يُزوهشهاى انجام شده بهنظور بهبود مطالعات آتى، از مهمترين راهكارهاى تحقق توسعه بايدار و

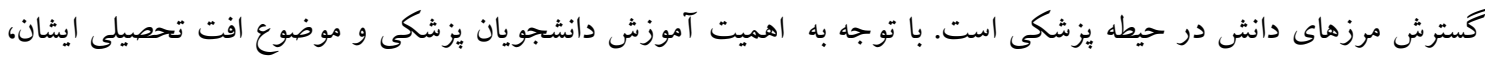

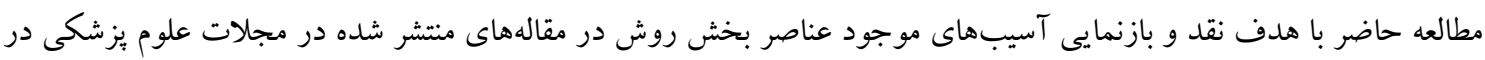
حوزه افت تحصيلى انجام شد.

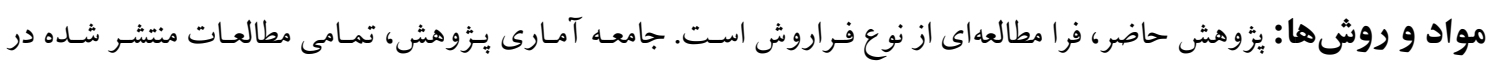

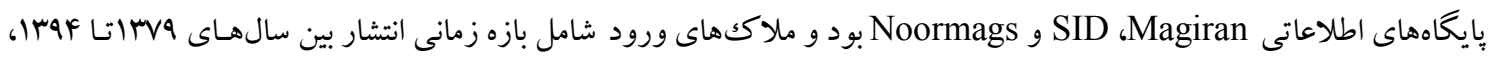

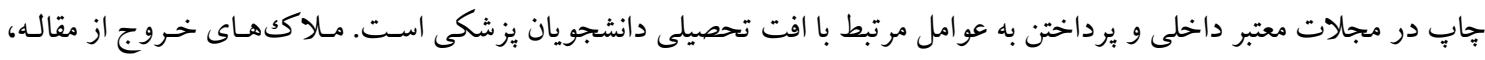

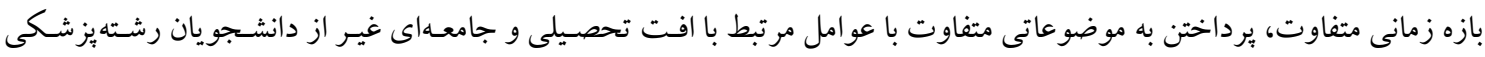

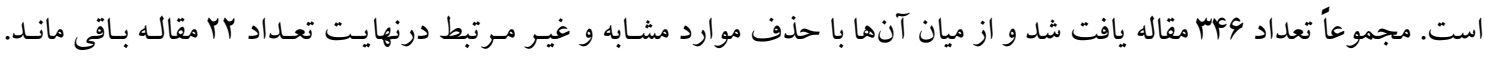

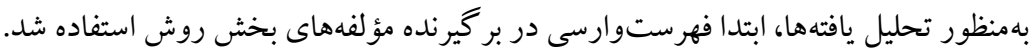

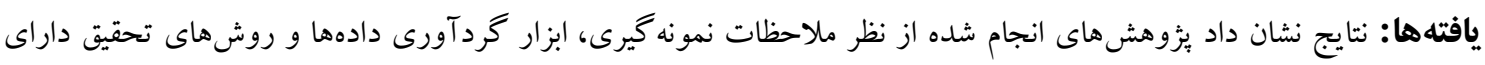

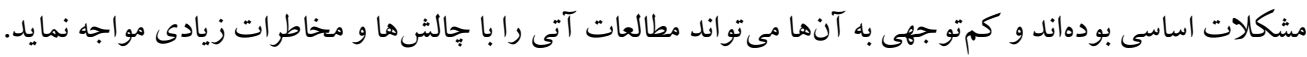
نتيجه كيرى: به نظر مىرسد توجه افر اطى به محتوا و كم توجهى به ظر افتهاى بخشروش، زمينهساز افت كيفيـت مطالعـات شـده

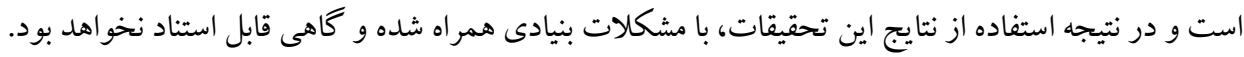
كلمات كليدى: فرا مطالعه، فراروش، روش تحقيق، افت تحصيلى

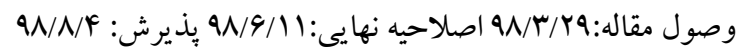


انتخاب روش نمونه گيرى بنا بر مقتضيات يزوهش از انواع روشهاى نمونه گيرى تصادفى و غير تصادفى استفاده

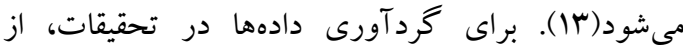
ابزارهاى كوناكونى جون مدار كك و اسناد، مشاهده، مصاحبه و برسشنامه مىتوان استفاده كرد(19). روايى و بايايى، دو مؤلفه اساسى ابزار گردآورى دادههاست. روايى نشان مىدهد كه ابزار منتخب تا جه حد آن جهه را كه بايد بسنجل، سنجيده است. جهار روش رايج سنجش روايى شامل مال صورى، محتوايى، سازه و ملاكى است. بايايى نشان مىدهد

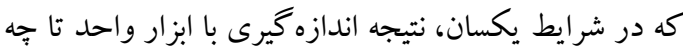
حد همسانى درونى دارد(IV). در روايى صورى، ساختار

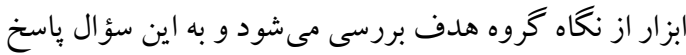
داده مىشود: آيا ابزار طر احى شده بهصورت ظاهرى باهن هدف مطالعه مرتبط است؟(זا). روايى محتوا، ويز گى ساختارى

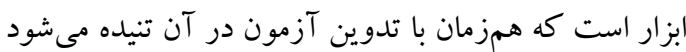
و براى تعيين روايى صورى و روايى محتوا از نظر

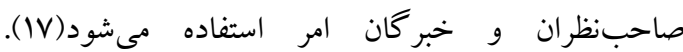

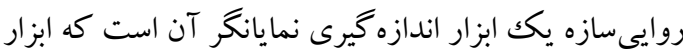

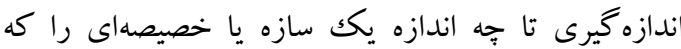
مبناىنظرى دارد مىسنجد(r|)، براى محاسبه روايى سازه

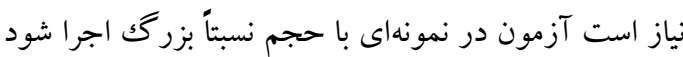
و سبس با انجام تحليل عامل اكتشافى و تأييدى عوامل

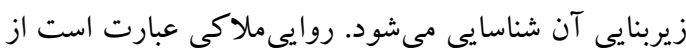
كار آمدى يك ابزار اندازهيرى در بيشبينى رفتار فرد در

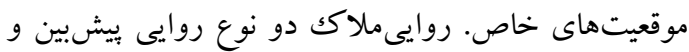

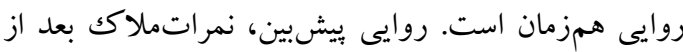

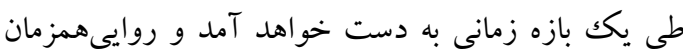
كه دادههاى حاصله از دو اندازهيرى در يككزمان در

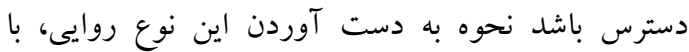
محاسبه ضريب همبستگى ميان آزمون مورد نظر و آزمون

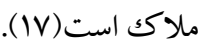

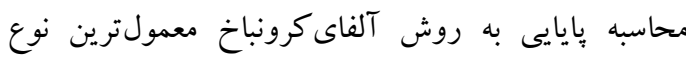

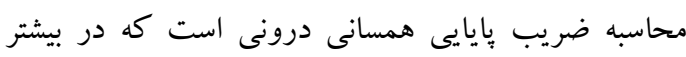

مقدمه افت تحصيلى در دانشجويان يكى از مهمترين نخرانىهاى مؤسسات آموزش عالى است( ( ا )؛؛ زيرا اين بديده به طور مستقيم و غير مستقيم خسارات زيادى را به فرد، خانواده و جامعه وارد مى سازد(r). افت تحصيلى، بار سنخين اقتصادى به جامعه تحميل مى كند و يرورش يافتن نيروى متخصص ناكار آمد، منجر به خدمات اجتماعى باكيفيت بايين خواهد لهد شد و از جنبه فردى، مشكلاتى همجيون ارتباط نامناسب با باسيا محيط و كاهش اعتمادبهنفس را در بى خواهد داشت(F). دركك بهتر عوامل مؤثر بر افت تحصيلى كليدى براى بهبود عملكرد موسسات آموزش عالى است(1) و تحقيقات متعددى عوامل مرتبط با افت تحصيلى را بررسى كردهاند(9-ه). فراروش، مرور بخش روش تحقيقات به صورت انتقادى است(·() و شامل تحليل رويكرد، روشهاى نمونه گيرى، روش نكارش فرضيهها، متغيرها، جامعه و نمونه و هر آن جه كه به بحث روش شناسى مربوط است(Y)، (1). يُزوهشها از نظر رويكرد به سه نوع كمّى، كيفى و آميخته طبقهبندى مىشوند. يُزوهشهاى كمّى كه در آنها متغيرها مشخص است و دادههاى تحقيق از نوع كمّى است(rا). يُزوهش كيفى، كه دادهاى تحقيق، كيفى هستند و محقق در يى ياسخ به سؤالهاى يُوهش است و يُزوهشهاى

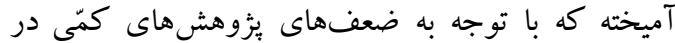
عدم عمق و ريشه كافى در بررسى متغيرها و ضعف يُزوهشهاى كيفى كه عموماً تعميميذيرى آن اندك است،

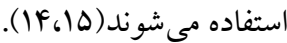
جامعه و نمونه آمارى، از مهمترين موارد روش يُزوهش است. درصورتى كه به دليل محدوديتهاى زمان يا بودجه و يا نيروى انسانى، تمامى اعضاى جامعه آمارى، بررسى نشوند

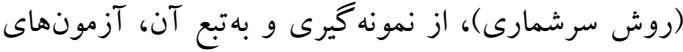
آمارى استفاده مىشود. محقق با دو تصميم اساسى در مورد روش نمونه گيرى و حجم نمونه روبهروست. در تعيين حجم

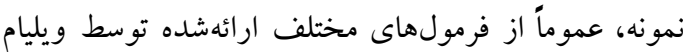
كو كران و يا جدول كرجسى و مور كان استفاده مىشود. در اردان 
اتلاف منابع انسانى و غير انسانى نظام آموزشى مى گردنسد.

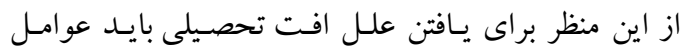
مختلفى نظيـر انخيزه، هـدف، هـوش، اضطر اب امتحـان، برنامهريزى، امكانات و تجهيزات و فرهنگى خـانو اده و ميزان عزت نفس را مورد توجه قـرار داد(Y)-YYY). مـرور

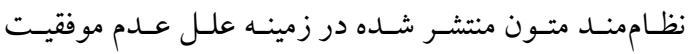
تحصيلى دانشجويان دانشگاههـاى علوم يزشكى، نشـان داد

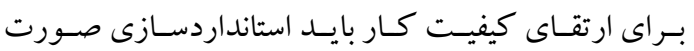

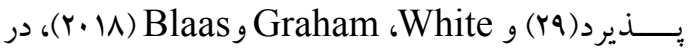
تحقيق خود، مشخص كردند كه بيشتر تحقيقات، در طراحى خود ضعف دارند( •r). از اهداف اصلى مؤسسات آموزش عالى، در كمترين حد

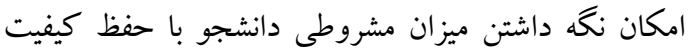
تحصيل و تدريس، در حد بالا است(اسل) و استفاده از نتايج

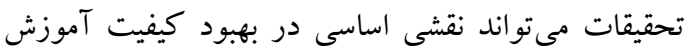

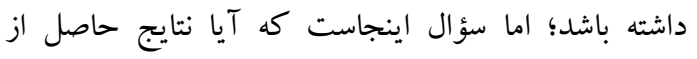
تحقيقات قابل استفاده است. هدف اصلى يزوهش حاضر اين

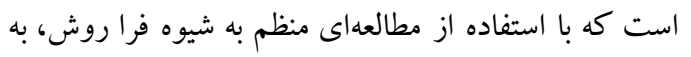

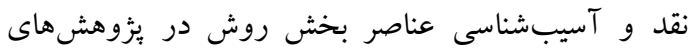

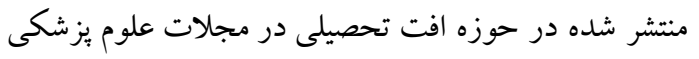

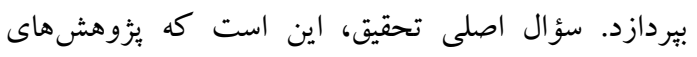

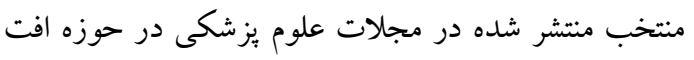
تحصيلى، از نظر رويكرد و روش تحقيق، جامعه و نمونه

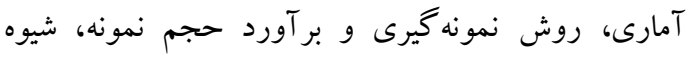
كردآورى دادهها، روايى و بايايى ابزار تحقيق تا جه ميزان

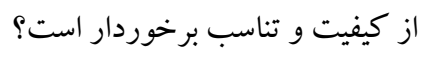

\section{مواد و روشها}

با توجه بـه اينكـه يافتـهـاى ايـن مطالعه در شـناخت و حـل

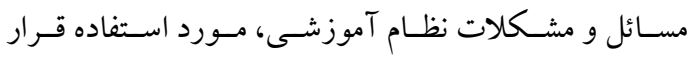
مى گيرد، اين بزوهش از نظر هدف، كاربردى، از نظر شيوه

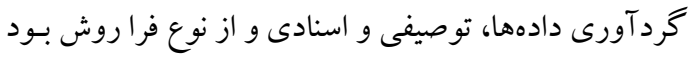

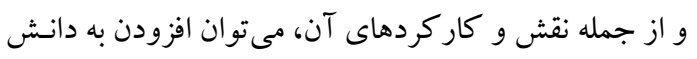

مطالعات از آن استفاده مىشود و معرف ميزان تناسب كروهى از گويههايى است كه يك سازه را مىسنجند(rا). در روش دو نيمسازى، يكك آزمون به دو نيمه تقسيم شده و رابطه همبستخى بين دو نيمه آزمون سنجيده مىشود(IV). روش فرمهاى موازى، دو آزمون معادل يا موازى براى يك ليك مطلب يا موضوع تهيه مى كنند و آنها را در فاصله زمانى كو تاهى به يك گروه واحد از آزمون شوند كان مىدهند. دو

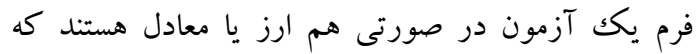
ميانكين و واريانس آنها برابر باشند(IV). در روش تكرار

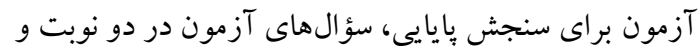

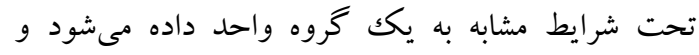

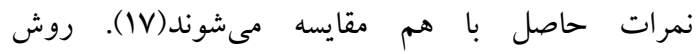
كودرريجاردسون، همسانى درونى بين سؤالها است و براى آزمونهايى كه ياسخ آنها به شكل صفر و يكك (صحيح يا درديا غلط) بيان مىشود مفيداست(r|). يزووهشها داراى هدف و

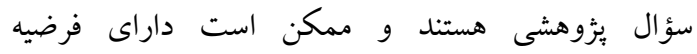
باشند(19). هدفهاى يثوهش، نتايج مورد انتظار از انجام

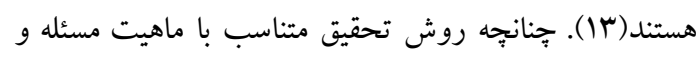

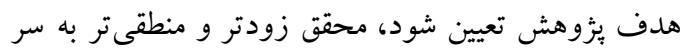

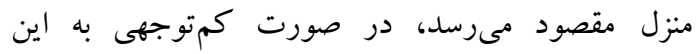

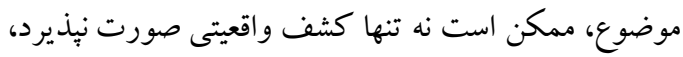
بلكه بر حيرت او افزوده شود و به ناكزير وى را به به انكار

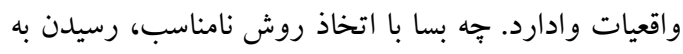

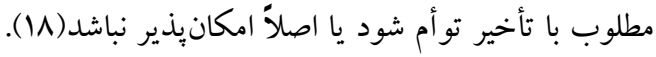

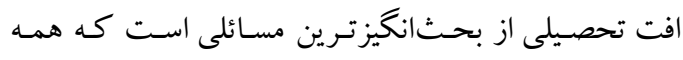

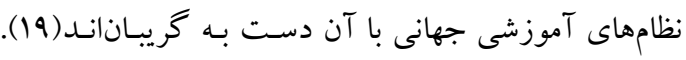

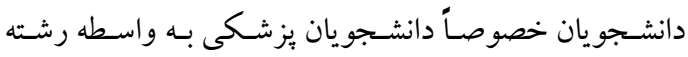
تحصيلى و حساسيت كارى در دوران تحصيلات دانشگاهى

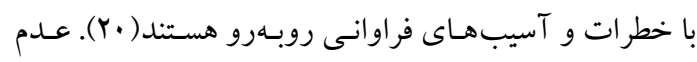

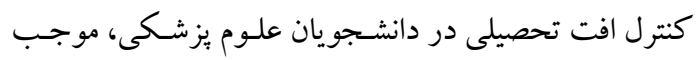

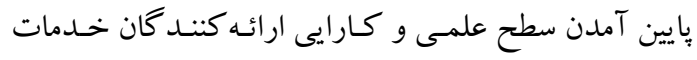

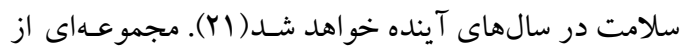
عوامل وجود دارند كه باعث افت تحصيلى و بـه تبع آن آن 
بازهزمـانى مـورد نظـر جـاب نشـده بودنـد. Y- مقـالاتى كـه

بهبررسى عوامل مرتبط با افت تحصيلى نيرداختند ب- مقـالاتى

كه افت تحصيلى را در جامعهاى غير دانشجويان رشتهيزشكى

$$
\text { بروسى كردند. }
$$

انتخاب مقالات بـه ايـن صـورت انجـام كرفـت كـه ابتـدا در يايگًاه داده مگك ايران (Magiran)، جستجو با عبـارت (افـت تحصيلى" و معادلهاى آن انجام شد. تعـداد ••1 مقاله يافت شد و از ميان آنها اب مورد بـا مـلاككهـاى ورود بـه تحقيـق مطابقت داشـتند. در پايخحاه جهاد دانشـاهى (SID) تعـداد مقالات يافت شده FA عدد بود كه از ميـان آنهـا، وبمـورد شـامل مـلاككهــاى ورود بـهـ تحقيـق نمسى شـدند. در بايخــاه نورمخس (Noormags) تعداد وبا مقاله يافت شـد كـه مورد آن در ملاككهاى مورد نظـر مقاله مطابقت داشـت. از ميان مقاله هاى مطابق با ملاكك هاى بثزوهش، تعـداد با مقاله مشابه بودند كه در نهايـت تعـداد Yr مقاله بـاقى مانــده مـورد بررسى قـرار گرفتـــ. نمسودار زيـر، مراحل جستجو و ورود

مطالعات را نشان مى دهد.
موجــود، دربــاره يــك برنامــه ويــزه و ييشــبرد تحقيـق و روش شناسـى، اشـاره كـرد(19). يـرّوهش حاضـر بـا هـدف بررسى كيفيـت كَزارش عناصـر مربـوط بـه بخـش روش در مقالههاى منتشر شـده در حـوزه افت تحصـيلى در مجـلات

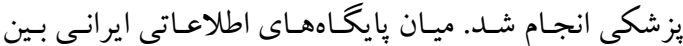
تحقيقات موجود اشتراكات وسيعى وجود دارد، از ايـنرو بـا

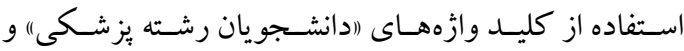
"اعو امل موثر بر افت تحصيلى") و (مشـروطى)" يـا (مـردودى)" و تر كيب اين دو وازه، مقالههــاى منتشـر شـده در پايخـاههـاى

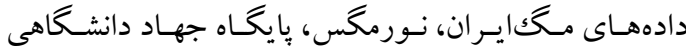
كه شامل تمامى مقالات (Noormags و SID, Magiran)

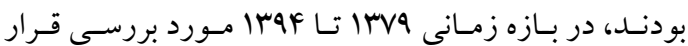
كرفتند. ملاككهاى ورود مقاله در اين مطالعه عبارت بود از:

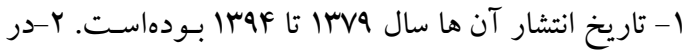
مجلاتمعتبر داخلى جاب شدهباشـند. r-بــبر رسـى عوامـل مرتبط با افت تحصيلى يرداخته باشند و F-تحقيقـات بـر روى

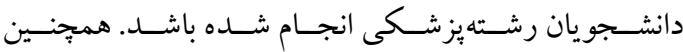
ملاككهاى خروج از مقاله عبارتبود از: ا-مقـالاتى كه در

\section{شكل ا. ورود و خروج مقالات به تحقيق}

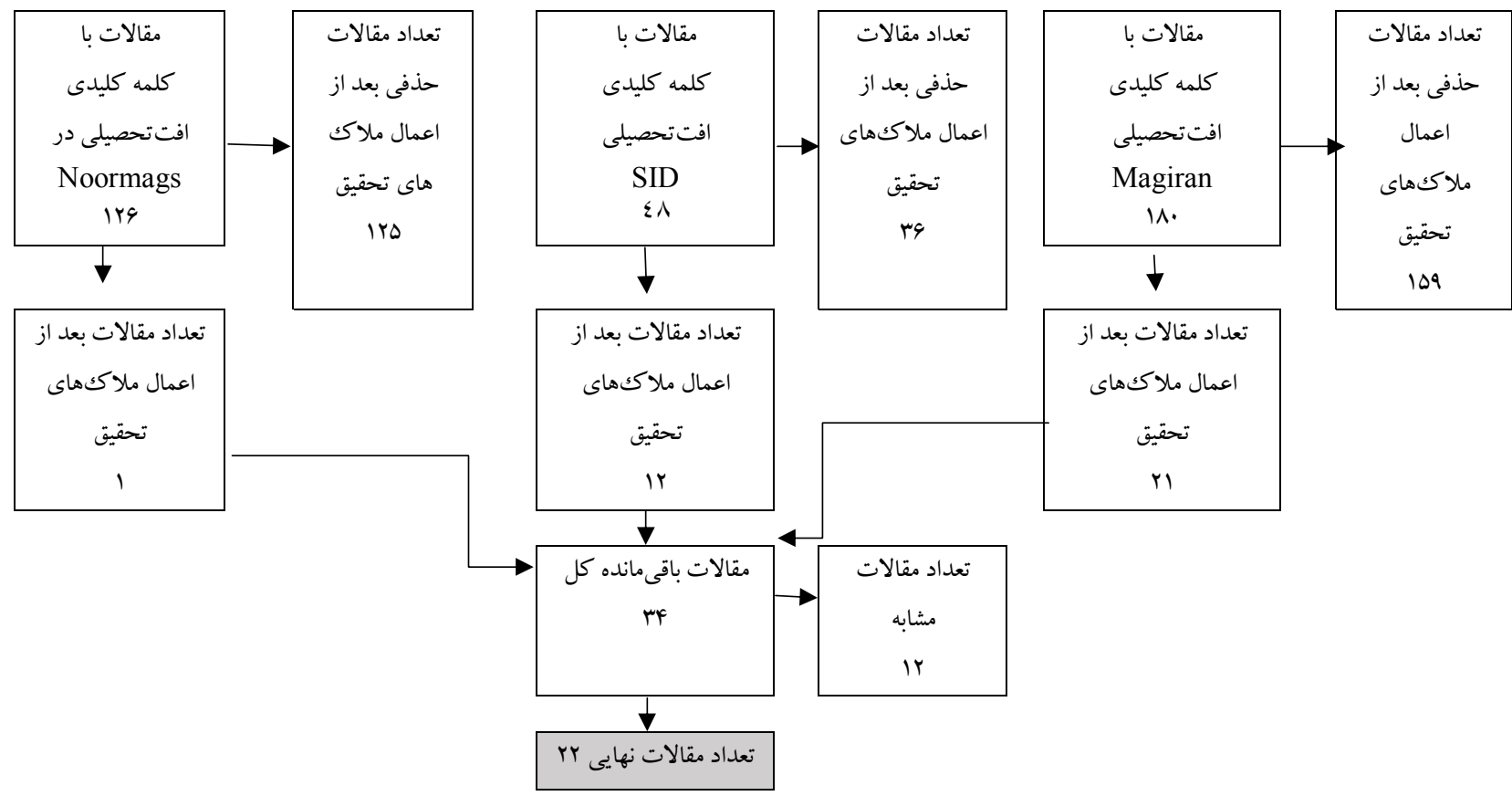

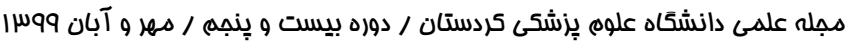


نمونه گيرى نبوده است و تحقيق انجـام شـده مطالعهـ مـوردى

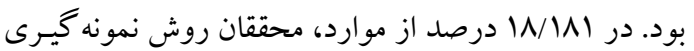

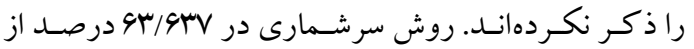
موارد است و بيشترين روش را تشكيل مسىدهـد. روشهـاى نمونه گيرى خوشهاى جندمر حلـهاى و تصـادفى طبقـهاى، هـر كدام F/DFD درصد از مـوارد و روش نمونسه گيـرى تصـادفى

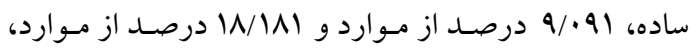
نمونه گيرى در دسترس بـوده اسـت كـه دو مـورد از F مـورد نمونه گيرى در دسترس مربوط به تحقيقات كمّى بوده اسـت. بررسى روش هاى محاسبه حجـم نمونـه در تحقيقـات بيـانگر

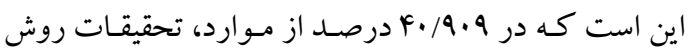
سرشمارى و مطالعهه مـوردى و مـرورى بـودهانـد كـه بنـا بـر مقتضيات يزوهش نيازى به محاسبه حجم نمونه نيسـت. در r r تحقيق، با فرمول كو كران حجم نمونه محاسبه شده است. در 11 مورد معادل با •ه درصد تحقيقات محققـان حجـم نمونـه

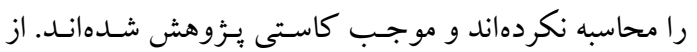
ميان يزوهش هـايى مـورد بررسى در 9 مـورد از روش خـود

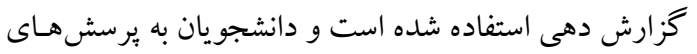
درج شده در فهرست وارسى يا برسشنامه ياسـخ دادهانـد. در ا مورد اطلاعات با مصاحبه و مشاهده جمع آورى شده است و در امــورد از اسـناد كتابخانـهاى (مقــالات جــاب شــده) استفاده شـده اسـت و در سـاير مـوارد جمـع آورى دادههـا بـا استفاده از اسناد و اطلاعـات درج شـده در برونـده تحصـيلى دانشـجويان بــوده اسـت. ايسن اطلاعـات شـامل اطلاعــات

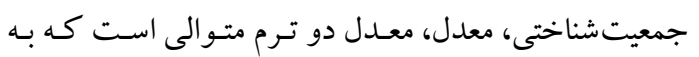
تفكيـك در جـدول شـماره ا درج شـده اسـت. در جـدول

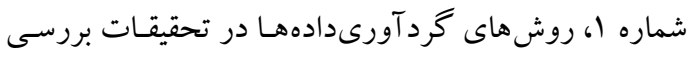

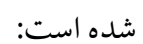

بهمنظور تحليل يافتهها، ابتدا فهرستوارسى تهيه شد كه با استفاده از آن، كار جمع آورى دادهها به گونهاى دقيقتر و جامعتر صورت گرفت. اين فهرستوارسى شامل مؤلفههايى نظير رويكرد تحقيق، فرضيهها، اهداف، جامعه و نمونه آمارى، روش نمونه گيرى، روش آمارى، روايى و پيايايى تحقيق بود؛ كه مجموعاً كيفيت مقالات ناميده شدند. محتوا و موارد اين فهرستوارسى بر اساس مصاحبه با هاستاد درس روش تدوين شد، لذا ابزار از روايى محتوا لازم برخوردار بود. بايايى اين ابزار به روش بازآزمايى و به مقدار

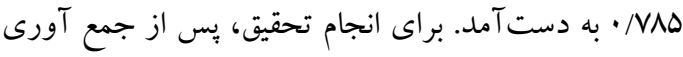
تحقيقاتى كه در ملاككهاى ورود به تحقيق صدق مى كردند، هر تحقيق ابتدا جند بار مورد مطالعه قرار گرفت. آنگاه با توجه به مطالب و گزارش يافتهاى تحقيق، به سؤالات فهرست وارسى پياسخ داده شد و مجموعاً فهرست وارسى، براى تحليل يافتهها آماده شد. براى له شناسايى نقاط ضعف و قوت روشهاى تحقيقات گذشته از آمار توصيفى ساده به صورت فراوانى و درصد و از نرم افزار MAXQDA استفاده شد.

يافته ها با بررسى مقالات و فهرست وارسىهاى جمـع آورى شـده، مشخص شد اكثريت بثزوهش هـا بـهروش كمّى انجـام شـــه

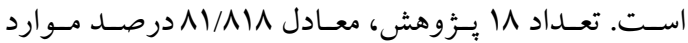

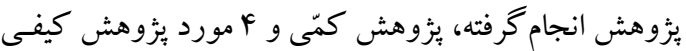
بوده است. در هيج مـوردى، يـروهش آميختـه انجـام نكرفتـه است. بررسى فراوانى روش هاى تحقيق مـورد اسـتفاده نشـان مىدهد كه مطالعه توصيفى ـ تحليلى از نوع مقطعى بيشـرين روش مــورد اسـتفاده در تحقيقـات بــوده اسـتـ. بررسـى روش هاى نمونه گيرى بكـار رفتـه در تحقيقـات، نشـان داد از

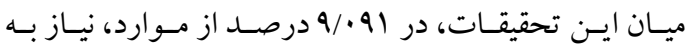




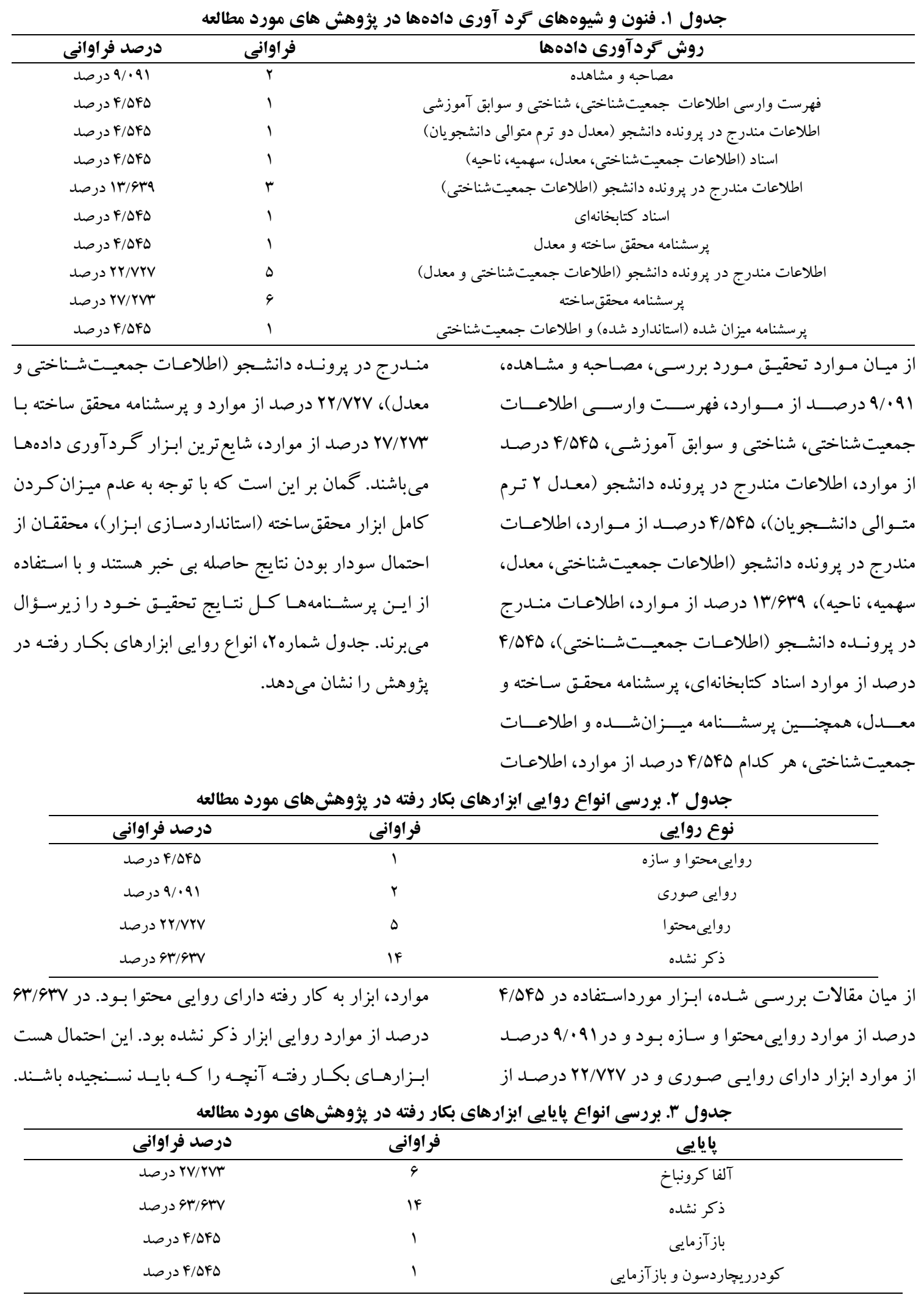

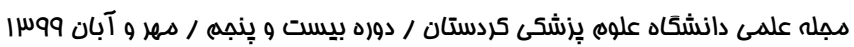


بكار گر فته شده بود. همجنـين در ميـزان پايـايى ذكـر نشـده اسـت. بـيم آن مسىرود كـه ابـزار استفادهشده يايايى نداشته باشد و نتايج حاصله را سودار كند. با توجه به تعريف در صورت عدم يايايى ابزار بكار رفته روا نيز نخو اهل بود.
جدول شماره ّا، يايايى ابزارهاى بكار رفتـه در يـروهشهـاى

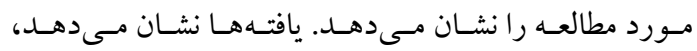
روشهاى محاسبه پيايايى در مطالعات مـورد بررسى، آلفـاى

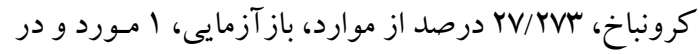
ا مورد هـم از هـر دو روش كودرريجاردسـون و باز آزمـايى

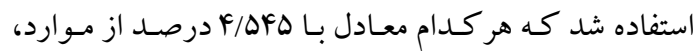

\begin{tabular}{|c|c|c|}
\hline درصد فراوانى & فراوانى & كزارههاى مسئله يخزوهش \\
\hline ( & rI & يُزوهش هاى داراى هدف \\
\hline F/DFD & 1 & ئزوهش بدون هدف \\
\hline | & r & يُروهش هاى داراى سؤال يُروهشى يا فرضيه \\
\hline (9.9.9 9 درصد & r. & يُزوهشهاى بدون سؤال يُروهشى يا فرضيه \\
\hline
\end{tabular}

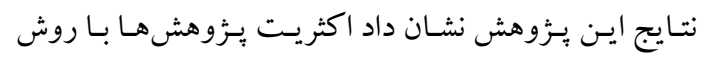

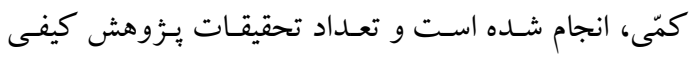
اندكك بوده است و در هيج موردى يـروهش آميختـه انجـام

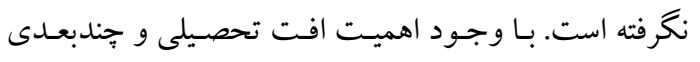
بودن عوامل مرتبط با آن، محققان در اكثريت موارد با روش كمّى به دنبال بررسى و تحقيق و شناسايى عو امـل هسـتند در

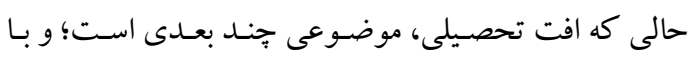
توجه به عميق و زرفانكر نبودن نتايج بثزوهش هاى كمّى (rV)

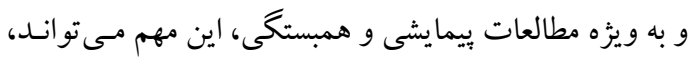
ضـرورت بازانديشـى در اسـتفاده از رويكردهــاى كيفـى و

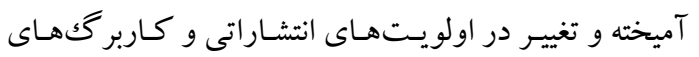
ارزيابى مجلات از مقالههاى غالباً كمّى به كيفى و آميخته را

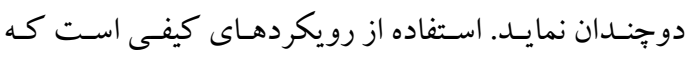
مى تواند يديده مورد مطالعه را با شيوهاى كلنكر و بافتارمنــ مورد بررسى قرار داده و يافته هاى عميقى را بـه دسـت دهـد، بسـيار محــدود بـوده اسـت و ايـن امـر، نشـانهاى از اسـتيلاى رويكـرد كمّىى و اثبـات گرايانـه در حسوزه مطالعـات علـوم انسانى (Tس و r M) و به ويزٔه در اطراف موضوع مـورد مطالعهـ

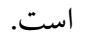
در موضوع نمونه گيرى، درصد تحقيقاتى كـه روش محاسـبه حجم نمونه در آنها بيان نشده بود، نيز قابل توجه اسـت كـه له اين موضوع نيز مىتواند از نقايص تحقيقات به شمار مىرود.
جدول شماره F، فراوانى و درصد فراوانى بيان هدف، فرضيهها

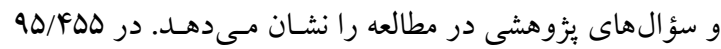
درصد از مقاله هاى بررسى شده، هدف و تنها در ا9 \$/9 درصد

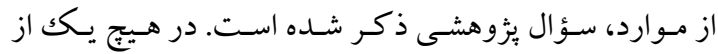
يُزوهش ها، فرضيهاى بيان نشده بود. هم:جنين ا مورد فاقد تمـام موارد هدف، سؤال يزووهشى و فرضيه بـود. همجنـين شناسـايى دانشجو دجار افت تحصيلى با استفاده از تعـاريف كمسى افـت تحصيلى بـوده اسـت و در تمـامى تحقيقـات مشـروطى و عـدم كذراندن واحد درسى به عنوان تعريف افت تحصسيلى در نظر

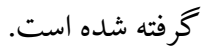

نقد علمى، يكى از قوىترين محر كها و راههاى اعتلاى آكاهى علمى است(ها). به كمكك نقد است كه يكك اثر اعتبار مىيابد و نقاط ضعف و قوت آن عيان و موجب اصلاح مداوم الكوهاى دانش بشرى مىشود( ( I). با توجه به ضرورت نقد آثار علمى، حال اين سؤال مطرح مىشود كه آثار علمى منتشر شده (كتاب، بياياننامه، رساله و مقالات) در محافل علمى ايران نيازمند نقد موشكافانه نيستند؟ نگًاه نقادانه بر بايانانامهاى دانشخاهها حاكى از وجود اشكالات و نواقص روشى، روششناسانه و ساختارى

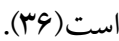


وجود ندارد از ابزارهـايى كـه در تحقيقـات بيشـين سـاخته و ميز ان شده است، استفاده شود. از سوى ديخر عدم توجه به فرضيه و سؤال ئزوهشى در تحقيقات جاى بررسى بيشترى دارد. هر تحقيق، تلاش براى رسيدن به ياسخ يكك يا جند سؤال است. فرضيه حدس و كمان هوشمندانه محقق براى يافتن پاسخ يكك مسئله است. نوعى ويشبينى است، بر پايه دانش قبلى محقق، مشاهدات يراكنده معقول و در ارتباط تنگاتنگك با مشكل و موضوع تحقيق، انجام مى گيرد. نبود فرضيه يا سؤال بزّوهشى، در مطالعات تحليلى، ارزش مطالعه را بسيار تنزل مىدهد.

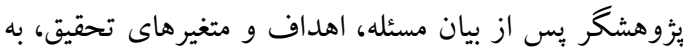
تدوين سؤالهاى تحقيق اقدام مى كند و به طور طبيعى روشهاى تحقيق بر اساس سؤالهاى تحقيق انتخاب مىشوند. همجنين يكى از ويز گیىهاى يك محقق ماهر، توانايى او در تدوين سؤالهاى تحقيق است. يك طرح تحقيق خوب بر يايه سؤالهاى تحقيق بنا مىشود. در حالى كه در تحقيقات بررسى شده سؤالهاى تحقيق و فرضيهها بهطور قابل توجهى مورد غفلت واقع شده بودند. از جمله محدوديتهاى اين تحقيق اين است كه با تمركز بر تحقيقات انجام شده و منتشر شده در زمينه عوامل مؤثر بر افت تحصيلى در ايران انجام شده و نمىتوان آن را به همه

مجلات تعميم داد.

\section{نتيجه كيرى}

اجراى هر بثزوهشى از جمله تحقيقات آموزشى بررسى عوامل مرتبط با افت تحصيلى دانشجويان يزشكى، همراه با هزينههاى مالى و زمانى محققين است و از سوى ديخر، دانش آموختخان رشته يزشكى با توجه به نوع حرفه خود، نياز دارند بر كل مطالب دوره تحصيلات دانشگاهى خود تسلط كامل داشته باشند و افت تحصيلى اين دانشجويان و عدم كسب اهداف آموزشى، هزينهاى دو جندانى خواهد داشت كه خود بر حساسيت يزوهش ها در زمينه اين مطلب
اكر نمونه مورد بررسسى در يـرّوهش، مُعـرف جامعـه نباشـــ، نتايج قابل تعميم نخواهد بود. لازم به ذكر است كـه اسـتفاده از عبارت (فرمول كو كران)) بدون مشخص كردن نوع فرمول و دليل انتخاب آن، دو خطاى متـداولى اسـت كـه در غالـب مقاله ها ديده مى شود. به ديخر سخن، نامشخص بودن نوع و

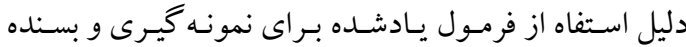
كردن اين مقالههـا بـه ذذكر عبـارت فرمـول كـوكران، نشـانه

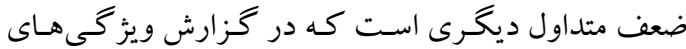
بخش روش ديلده مى شود. ضمناً وجود يا عدم وجود مطالعه. مقدماتى و جِكونگكى محاسبه حجم نمونه در اغلب مطالعـات كمّى، به گونهاى كلى گززارش شـده بـود و عناصـر فرمـول اشاره شده نـامعلوم، مـبهم و نـاقص گَزارش شـده اسـت. در برخسى از مقالـههـا هـم بــراى تبيسين حجــم نمونـه از عبـارت (جدول موركًان) استفاده شده است، بدون توجه به اينكه اين جــدول و مقــادير گـز ارش شــده آن بــراى حجــم نمونسه در خصوص متغيرهاى دووجهى تناسب دارد. يافته هاى مطالعه حاضر حاكى از اين بود كـه گسـتره وسـيعى از بزظوهش هايى كـه در زمينه افـت تحصـيلى رشـته بز شكى انجـام شــده اسـت محقـق بـه تنهـايـى عوامـل مـؤثر بـر افـت تحصيلى را بـا يـك بر سشـنامه خـود سـاخته، بررسىى نمـوده اسـت و تنهـا در يـكك مـورد از مـوارد بررسـى شــده ابـزار اندازه گيرى دار اي روايى سـازه اسـت. در حسالى كـه روايسى سازه، اساس كار، دادههـاى دنيـاى واقعى اسـت و تناسـب و ساز گارى نتـايج بـه دسـت آمــده را بـا نظريـهــاى پايـه كـار مقايسه مى كند. در روايى سازه، انتظار مىرود عو امـل نظرى مورد نظر، واريانس آزمونها را تـدوين كنــد يـا بـه عبـارت كلى تر ابزار مورد استفاده، سازههاى اصلى را مـورد سـنشش

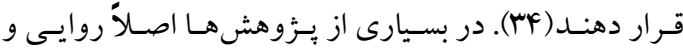
يايايى ابزار رادر نظر نخر فته بودند. در حسالى كـه استفاده از

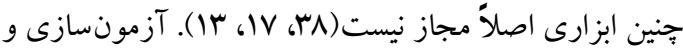
ميز ان كردن يـك آزمـون شـامل مراحل بيتجيـدهاى اسـت و ييشنهاد مى شود هنگًامى كه شناخت كافى براى ساخت ابـزار 
و متغيرهاى تحقيق، به تدوين سؤ الهاى تحقيق اقدام مى كند. سؤالات تحقيق بايد بر اساس اهداف و متغيرهاى تحقيق و به صورت درست، تدوين و بيان شوند؛ زيرا به طور طبيعى روشهاى تحقيق بر اساس سؤالهاى تحقيق انتخاب مىشوند همجنين يكى از ويزَ گیىاى يك محقق ماهر،

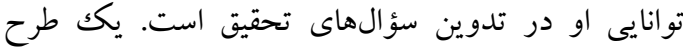
تحقيق خوب بر بايه سؤالهاى تحقيق بنا مىشود. در حالى كه در تحقيقات بررسى شده سؤالهاى تحقيق و فرضيهها مورد بهطور قابل توجهى مورد غفلت واقع شده لهاني بودند. در بسيارى از تحقيقات انجامشده در مورد افت تحصيلى دانشجويان يزشكى، تعريف عملياتى متغير افت تحصيلى، معدل كسب شده توسط دانشجو است(ها-19). در حالى كه به علت اهميت و حساسيت اين رشته، تعيين شاخصهايى دقيقتر از تنها معدل دانشكاهى جهت تشخيص افت تحصيلى را مىطلبد. با توجه به حجم بالاى تحقيقات كمى در زمينه افت تحصيلى، بررسى عميق و همه جانبه افت تحصيلى مغفول واقع شده، يِينهاد مىشود كه در يثزوهشهاى كيفى شاخصهاى شناسايى افت تحصيلى دانشجويان يزشكى بررسى شود. همجنين محققان در تحقيقات خود از برسشنامه محقق ساخته براى سنجش برسئ برد عوامل مؤثر بر افت تحصيلى استفاده مىكنند، بيشنهاد مىشود كه براى سنجش عوامل مؤثر بر افت تحصيلى در

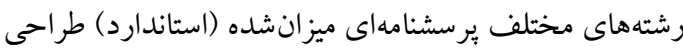

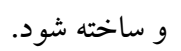

\section{تشكر و قدردانى}

اين مقاله بركرفته از يافتهاى رساله دكترى تخصصى رشته سنجش و اندازهگيرى دانشگاه تهران بوده و داراى كد اخلاق IR.UT.PSYEDU.REC.1398.024 است. نويسندكان بر خود لازم مىداند از مانشجويان شر كت كنند كان در يُزوهش به دليل همكارى در گردآورى

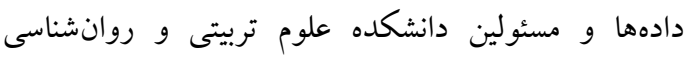

مىافزايد و لزوم دقت و رعايت اصول و قوانين روش تحقيق را افزايش مىدهد. نتايج اين مطالعه نشان داد، با وجود اهميت افت تحصيلى و جندبعدى بودن عوامل مرتبط با آن، محققان در اكثريت موارد با روش كمى به دنبال بررسى و تحقيق و شناسايى عوامل هستند؛ اما نه تنها هنوز عمق و ريشه اين موضوع شناسايى نشده است بلكه ميزان آن رو به افزايش است. اين مطلب گوياى اين امر است كه بى بردن به عوامل زير بنايى اين موضوع نيازمند تحقيقات كيفى و همه انه جانبه است. در امر نمونه گيرى، درصد تحقيقاتى كه روش نمونه گيرى و روش محاسبه حجم نمونه در آنها بيان نشده بود نيز قابل توجه است و واضح است كه اين امر از موارد نقص تحقيقات به شمار مىرود. اكر نمونه مورد بررسى در يُزوهش، معرف جامعه نباشد، نتايج قابل تعميم به جامعه نخواهد بود. گستره وسيعى از يُزوهشهايى كه در رشته يزشكى انجام شده است محقق به تنهايى عوامل مؤثر بر افت تحصيلى را با يكك يرسشنامه خود ساخته، بررسى نموده

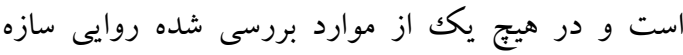
محاسبه نشده است. حتى در بسيارى از بزوهشها اصلاً روايى و بايايى ابزار را در نظر نخرفته بودند. در حالى كه بهان استفاده از جنين ابزارى اصلاً مجاز نيست. آزمونسازى و وإنى

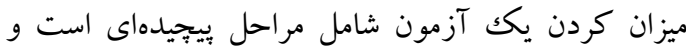
ي يشنهاد مىشود هنكامى كه اطلاعات كافى براى ساخت ابزار وجود ندارد از ابزارهايى كه در تحقيقات بيشين ساخته شده و ميزانشده است استفاده شود. از سوى ديخر عدم توجه به فرضيه و سؤال يُزوهشى در تحقيقات جاى بررسى بيشترى

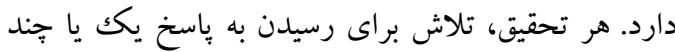

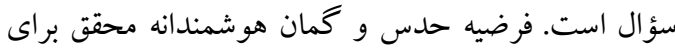

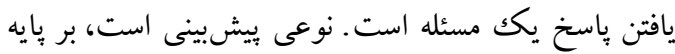

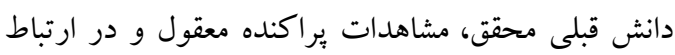

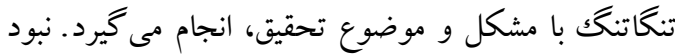

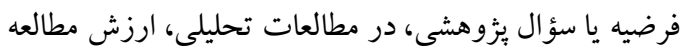

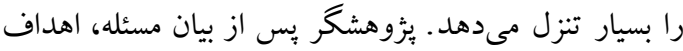




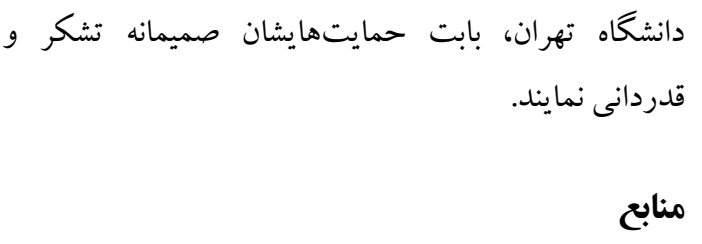

1. Al-Zoubi S M, Bani Younes MA. Low Academic Achievement: Causes and Results. TPLS. 2015; 5(11): 2262-2268.

2. Khan YA, Ahamad Z, Kousar, S. Factors influencing academic failure of university students. Int $\mathbf{J}$ Educ Admin Pol Stud. 2013; 5(5): 79-84.

3. Tovar E, Simon M. Academic Probation as a Dangerous Opportunity: Factors Influencing Diverse College Students' Success. Community Coll J Res Pract. 2006; 30(7): 547-564.

4. ONeill L D, Wallstedt B, Eika B, Hartvigsen J. Factors associated with dropout in medical education: a literature review. Med Educ. 2011; 45: 440-454.

5. Durso SO, Cunha JVA. Determinant Factors for undergraduate student's Dropout in accounting student department of a Brazilian Public university. Educ rev, [online]. 2018; 34Available from: http://dx.doi.org/10.1590/0102-4698186332

6. Choi HJ, Kim B. Uk. Factors Affecting Adult Student Dropout Rates in the Korean CyberUniversity Degree Programs. J Contin High Educ. 2018; 66(1): 1-12.

7. Kalimullina AM, Khodyrevab EA, Koinova-Zoellnerc J. Development of Internal System of Education Quality Assessment at a University. Int J Environ Sci Educ. 2016; 11(13): 6002-6013

8. Stinebrickner R, Stinebrickner T A. Major in Science? Initial Beliefs and Final Outcomes for College Major and Dropout. Rev Econ Stud. 2014; 81(1): 426-472 .

9. Lancia L, Petrucci C, Giorgi F, Dante A, Cifone MG. Academic success or failure in nursing students, results of a retrospective observational study. Nurs Educ Today. 2013; 33(12): 15011505 .

10. Barnett-Page E, Thomas J. Methods for the synthesis of qualitative research: a critical review. BMC Med Res Methodol. 2009; 9(59). Available from: https://doi.org/10.1186/1471-2288-9-59

11. Bench S, Day T. The User Experience of Critical Care Discharges: a Meta-synthesis of Qualitative Research. Int J Nurs Stud. 2010; 47(4): 487-499.

12. Mohammad Nejad Shurkaii M, Ghanani Arani M, Yazdani HR. The Meta-Method of research on factors affecting on customer satisfaction: A documentary analysis of master's degree dissertations and Ph.D. at Tehran's Universities. JBM. 2011; 10(2): 141-164.

13. Sarmad Z, Bazargan A, Hejazi E. Research methods in Behavioral Sciences. Tehran: Agah Press, 2013.

14. Mohammadzadeh Z, Salehi K. Pathology of scientific vitality and dynamism in scientific and academic centers: A study according to "Phenomenology". JMSP. 2015; 3(11): 1-25

15. Bazargan A. An Introduction to Qualitaive and Mixed Methods Research. Tehran: Didar Press, 2013.

16. Delavar A. Research methods in psychology and educational sciences. Tehran: Vierayesh Press, 2002.

17. Saif AA. Educational measurement, assessment and evaluation. Tehran: Dowran Press, 2018.

18. Fadaii GR. About the importance of research methodology and its application. Strategies for the Promotion of Humanities in Iran Conference. 2007 Feb. 12, Tehran, Iran. https://www.civilica.com/paper-socialscienceconf01-socialscienceconf01_144.html

19. Azad yekta M.Study of Coping Strategies and Attributional Styles as Predictors of School Dropt of Students in Azad Islamic University, Branch Islamshahr Branch. J Psychol Achiev. 2012;19 (1): 99-116.

20. Shams B, Farshidfar M, Hassanzadeh A. Effect of counseling on the achievement of university students with dropout. IJME. 2000; 1(1): 36-418.

هجله علمى دانشكاه علوه بِزشكى كردستان / دوره بيست و يَنجهم / دهر و آبان وسرا 
21. Jabraili M, Mousavi Vaezi SJ, Mikaeli P, Saadatyanov R, Aqlmad S. Evaluating the Influencing Factors of Educational Underachievement in Gifted and Talented Students of Urmia University of Medical Sciences. HMED. 2011; 4 (3): 21-25.

22. Tamanaefar M, Neyazi M, Amini M. Factors Influencing Students' Underachievement. TLR. 2007; 1(24): 39-52.

23. Koohi Nasrabadi M, Navabipour M, Ganji M, Safavi SM. Determining Organizational Factors Affecting Educational Failure of the Students and How to Control and reduce it (Case Study: University of Kashan). JOMC. 2013; 11(3): 141-168.

24. Haghdoust AA, Sadeghirad B, Shamsedini A, Nafisi Y, Dehghani MR, Ayatollahimosavi SA. The rates and examples of the academic achievement of medical students sent abroad. JCHR. 2010; 13(1): $1-10$.

25. Afzali M, Delavar A, Afzali A. Meta-Analysis of thesis' about Academic Failure. J Educ Meas. 2014; 5(17): 9-27.

26. Snyder KE, Adelson, JL. The Development and Validation of the Perceived Academic Underachievement Scale. J Exp Educ. 2017; 4(85): 614-628 .

27. Baslanti U, McCoach D. Factors related to the under achevement of university students. Turkey Roeper Rev. 2006; 28(4): 210-215.

28. Banerjee PA. A systematic review of factors linked to poor academic performance of disadvantaged students in science and maths in schools. Cogent Educ. 2016; 3(1): 1-17.

29. Fata L, Azari SH, Baradaran H, Atlasi R. A. Systematic Review of the Evaluation of Academic Decline in Medical Students. Strides Dev Med Educ. 2013; 10(2): 31-38.

30. White S LJ, Graham LJ, Blaas S. Why do we know so little about the factors associated with gifted underachievement? A systematic literature review. Educ Res Rev. 2018; 24: 55-66.

31. Rump M, Esdar W, Wild, E. Individual differences in the effects of academic motivation on higher education students' intention to drop out. Eur J High Educ. 2017; 7(4): 341-355.

32. Mohammadzadeh Z, Salehi K. Explanation of the Phenomenon of Scientific Vitality and Dynamism in Scientific Centers from Perspective of Academic Elites: A Study According to "Phenomenology". Rahbord. 2016; 25(79): 227-258.

33. Hafez Nia, MR. Preface to the Research Methodology in Humanities. Tehran: Samt Press, 2006.

34. Delavar A. [A farsi translation of] An introduction to psychometry and assessment theories [by Allen, M. \& Vandi, M.] Tehran: Samt press: 2000.

35. Iranpour Z. Identifying and Investigating the Factors Affecting Customer Satisfaction from AfterSales Services of Saipa Yadak Company in Tehran Using the Kano Model. [MA Thesis]. Tehran: Tarbiat Modarres University; 2004.

36. Mozaffari Khosravi H, Ehrampoosh M, Aghili H, Javadianzadeh F, Rahimdel T. An Evaluation of Graduates' Theses at Shahid Sadoughi University of Medical Sciences in Yazd. jmed. 2008; 2(2):27-35.

37. Salehi, K., \& Golafshani, N. Using mixed methods in research studies, an opportunity with its challenges. Int J Mult Res Approaches. 2010; 4: 186 - 191.

38. Hassanzadeh R. Research Methods in Behavioral Sciences. Tehran: Savalan Press, 2008. 